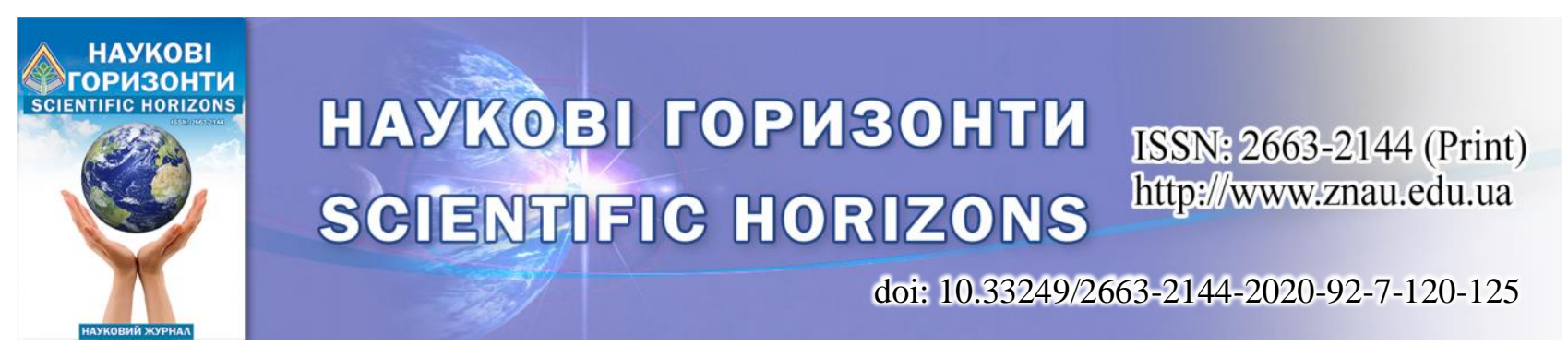

UDC 631.356 .2

\title{
INCREASING SUGAR BEET FEEDSTOCK QUALITY THROUGH INTENSIFICATION OF ROOT CLEANING AT HARVESTING
}

\section{Volokha}

Article info

Received

19.05.2020

Accepted

24.06.2020

Institute of

Bioenergy

Crops and

Sugar Beets

NAAS

25, Klinichna

Str., Kyiv, 03110, Ukraine

E-mail:

volmp@i.ua
Volokha, M. (2020). Increasing sugar beet feedstock quality through intensification of root cleaning at harvesting. Scientific Horizons, 07 (92), 120-125. doi: 10.33249/2663-2144-2020-92-7-120-125.

Given the import of fuel energy and lack of access to foreign sugar markets, the need to revive the sugar beet complex is an important factor determining the production of bioethanol from sugar beets in Ukraine. To stabilize the industry, it is necessary to introduce the production of bioethanol in beet processing plants, identifying priority measures for the development of biofuel production in our country and ways to establish the operation of sugar factories for the production of sugar and biofuels. Physical contamination of the heap of harvested roots, which mainly depends on the technical perfection of the working bodies of beet harvesters, leads to a decrease in the quality of raw sugar, because impurities and severely damaged, including diseases and pests, roots prevent the extraction of sugar, reducing the quality of diffusion juice and increasing the sugar content in the molasses. Known developments when installed on the root harvester additional cleaning and transporting devices complicated its design and overall dimensions. With this in mind, the aim of the study is to improve the quality of cleaning of roots during their excavation by modeling the surface of the cleaner-conveyor of the digging working body.

The research was carried out by methods of applied geometry, agricultural mechanics, analysis of variance using the software application MS Excel. Samples of heap of root crops were taken according to the methodology of the Institute of Bioenergy Crops and Sugar Beets. The most widespread among digging working bodies of modern root-harvesting machines of domestic and foreign production are diggers of disk type due to their ability to crush the soil well with a small amount of its fence, reliability of work on heavy soils and weedy fields and high productivity. In the upper rear part of the disk digging working body there is a beater or a screw auger, to which the roots are fed in a pile with the remnants of a disc cut of soil, buds and weeds. The disadvantage is the low cleaning capacity of the bittering device, which solely by impact overturns a pile of roots, or a screw with a screw winding, when the roots together with plant and soil residues accumulate in the rear area of the auger, which also leads to a decrease in productivity of the technological process of digging and deterioration of cleaning of roots.

Experimental field studies of the developed samples of new augers-conveyors of the disk digger established that at work of clearing surfaces with winding in the form of direct and inclined helicoids of a variable step at the increased hardness of soil the quantity of lumps in diameter more than $50 \mathrm{~mm}$ essentially decreases as in variants, and in relation to control. Indicators of impurities in the form of green mass and the number of damaged roots at medium soil hardness are the lowest in the case of using an inclined helical auger. The inclined helical auger on soils of the increased hardness also provided decrease in weight of the damaged root crops in comparison with the bither cleaner. Researchers of the Institute of Bioenergy Crops and Sugar Beets NAAS continue research to develop and improve technologies for growing and harvesting sugar beets in order to improve their productivity and quality of raw materials for processing into bioethanol and biodiesel.

Key words: sugar beet, roots, biofuels, technological quality of raw materials, disk diggers, helicoid. 


\title{
ПІДВИЩЕННЯ ЯКОСТІ ЦУКРОСИРОВИНИ ШЛЯХОМ ІНТЕНСИФІКАЦІЇ ОЧИЩЕННЯ
} КОРЕНЕПЛОДІВ ПРИ ЇХ ВИКОПУВАННІ

\author{
М. П. Волоха \\ Інститут біоенергетичних культур і цукрових буряків НААН \\ вул. Клінічна, 25, м. Київ, 03110, Україна
}

Зважаючи на імпорт паливних енергоносіїв та відсутність доступу на зовнішні ринки иукру, потреба у відродженні бурякоиукрового комплексу є важливим чинником, щу зумовлює виробництво біоетанолу з иукрових буряків в Украйні. Метою дослідження є підвищення якості очищення коренеплодів під час їх викопування шляхом моделювання поверхні очисника-транспортера викопувального робочого органа. Дослідження проводилися методами прикладної геометрії, землеробської механіки, дисперсійного аналізу з використанням програмного додатку MS Exсеl. Встановлено, що фізична забрудненість вороху зібраних коренеплодів, яка в основному залежить від технічної досконалості робочих органів бурякозбиральних машин, призводить до зниження якості иукросировини, адже сторонні домішки та сильно пошкоджені, в тому числі хворобами і шкідниками, коренеплоди заважають вилученню иукру, знижуючи доброякісність дифузійного соку та збільшуючи вмісту иукру в мелясі. Відомі розробки, де встановлені на коренезбиральну машину додаткові очищувально-транспортуючі пристрої ускладнювали ї̈ конструкцію і габаритні розміри.

Проби вороху коренеплодів відбиралися відповідно до методики Інституту біоенергетичних культур $і$ иукрових буряків. Найпоширенішими серед викопувальних робочих органів сучасних коренезбиральних машин вітчизняного і зарубіжного виробництва є копачі дискового типу завдяки їх здатності добре кришити трунт при малій кількості його забору, надійності роботи на важких трунтах $i$ забур'янених полях та високій продуктивності. У верхній задній частині дискового викопувального робочого органа розташовується бітер чи гвинтовий шнек, до яких подаються коренеплоди у купі із залишками підрізаної дисками скиби трунту, гички і бур'янів. Встановлено, що недоліком є низька очищувальна здатність бітерного пристрою, який виключно за рахунок удару перекидає ворох коренеплодів, чи шнека з гвинтовою навивкою, коли коренеплоди разом з рослинними та грунтовими рештками скупчуються у задній зоні шнека. Науковиями Інституту біоенергетичних культур і иукрових буряків НААН продовжуються дослідження з розробки і удосконалення технологій вирощування $і$ збирання буряків иукрових з метою підвищення їх продуктивності та якості сировини для переробки на біоетанол та біодизель.

Ключові слова: буряки иукрові, коренеплоди, біопаливо, технологічна якість сировини, дискові копачі, гелікоїд.

\section{Вступ}

Традиційно буряк цукровий розглядається як культура для виробництва білого цукру, між тим, завдяки високому вмісту в ньому цукрози, яка може бути перетворена у біоетанол, цукровий буряк є однією з небагатьох технічних культур, придатних для виробництва 3 неї біопалив (Polishchuk et al., 2018; Zhelezna et al., 2018; Logush et al., 2019)

Комплекс біологічних, фізичних і хімічних особливостей коренеплодів, що визначають перебіг технологічних процесів на заводі і вихід кристалічного білого цукру, $\epsilon$ показниками їх технологічної якості. Для сировини буряків цукрових характерні різкі зміни показників технологічної якості у процесі збирання i зберігання. Одним з найважливіших серед них $є$ фізичні властивості сировини: забрудненість вороху коренеплодів землею і залишками зеленої маси, механічні пошкодження коренеплодів, підв'яленість, підмороженість, дуплистість, ураженість хворобами (у тому числі кореневими гнилями) та шкідниками.

Коренеплід цукрового буряка - живий організм, який після викопування продовжує дихати подібно до періоду вегетації, споживає кисень, генеруючи при цьому тепло та виділяючи вуглекислий газ. Якість сформованої в кагати сировини за таких умов вочевидь погіршується внаслідок комплексу фізіологічних процесів, а іiі маса зменшується за рахунок цукрози, що витрачається на дихання і випарювання вологи при всиханні.

За даними НДІ цукрової промисловості під час переробки цукросировини кожний відсоток зеленої маси на коренеплодах призводить до 
зниження доброякісності дифузійного соку на 0,4-0,5\% і збільшення вмісту цукру в мелясі на $0,1 \%$. Загалом, при тривалому заводському зберіганні (більше 60 діб) сильно пошкоджених і забруднених землею та рослинними залишками коренеплодів внаслідок ураження кагатною гниллю, значно погіршуються кондиції сировини, а втрати цукру зростають у 5-7 разів.

Зменшення маси сировини залежить також від метеорологічних умов i на вітчизняних заводах за весь сезон зберігання коливається у межах 1,5-3,0 \% до первинної маси укладеного буряка. Зниження цукристості при тривалому зберіганні буряка прямо залежить від його організації. Основна доля втрат сахарози (до $75 \%$ ) припадає на процеси дихання (Chernyavskaya et al., 2013).

3 літературних джерел відомо, що дана проблема постає і в інших країнах світу: у Франції за середньорічного валового збору 33 млн т буряків втрати при зберіганні складають 100 тис. т, або 0,3\%. Середньодобові втрати цукру за період зберігання в Англії складають 160 г/т; в Ірландії - 200; у Франції - 400; в Німеччині - 450; у США - більше 450 г/т (Kuhar et al., 2013).

Продуктивність виробництва буряків цукрових та технологічна якість коренеплодів визначається рівнем застосовуваних механізованих технологій на всіх етапах від основного обробітку грунту до отримання бурякової сировини на заводі восени наступного року. Проте, якість викопаних коренеплодів значно залежить від технічної досконалості робочих органів бурякозбиральних машин, насамперед гичкорізів, копачів та очисників.

Викопувальні робочі органи подають разом 3 викопаними коренеплодами на наступні очисні системи коренезбиральної машини недопустимо значну масову кількість грунтових домішок (у середньому до $10 \ldots 15$ т 31 га). За умов підвищеної твердості (понад 4,0-4,5 МПа) і щільності грунту та значної забур'яненості поля різко зростає (до 13-15\%) кількість невикопаних коренеплодів і до $40 \%$ коренеплодів викопуються пошкодженими, обсяги безповоротної «доставки» родючих чорноземів на бурякоприймальні пункти заводів у вигляді домішок 3 брил землі сягають 42-47\% від загальної маси вороху коренеплодів, як, наприклад, у 1994 році, коли 3 господарств сировинної зони Погребищенського цукрового заводу на призаводський бурякопункт було привезено понад 25 тис. т землі і зеленої маси (Balan et al., 2000).

Цукровому заводу необхідно мати такі буряки, сік яких, по можливості, був би без сторонніх домішок, які заважають вилученню цукру. Однак, незважаючи на вимоги національного стандарту (Koreneplody tsukrovoho buryaka dlya promyslovoho pereroblyannya, 2014), цукрові заводи вимушені приймати некондиційну сировину. Скажімо, показники фізичної якості сировини, доставленої на Яреськівський цукровий завод (Полтавська область) у 2018 році за даними асоціації «Укрцукор» значно перевищили вимоги держстандарту (табл. 1).

Таблиия 1. Показники фізичної якості сировини (Яреськівський цукровий завод, 2018 р.)

\begin{tabular}{|l|c|c|}
\hline \multicolumn{1}{|c|}{$\begin{array}{c}\text { Характеристики } \\
\text { сировини }\end{array}$} & $\begin{array}{c}\text { Показники якісної сировини } \\
\text { (за масою), \% }\end{array}$ & $\begin{array}{c}\text { Показники прийнятої заводом } \\
\text { сировини (за масою), \% }\end{array}$ \\
\hline Загальна забрудненість, & $5,0-6,0$ & $10,0-15,0$ \\
\hline у т. ч.: & $0,1-0,5$ & $1,0-3,0$ \\
\hline - зелена маса & $8,0-10,0$ & $20,0-25,0$ \\
\hline $\begin{array}{c}\text { - значні механічні } \\
\text { пошкодження }\end{array}$ & & 20 \\
\hline
\end{tabular}

Для покращення очищення вороху керенеплодів на коренезбиральну машину встановлювали додаткові очищувальнотранспортуючі робочі органи, як, наприклад, пристрій що складається 3 чотирьох вальців, що зустрічно обертаються, і гвинтового шнека, розташованих фронтально слідом за дисковими копачами машини МКП-6 (Golovach et al., 2012) Така комбінація очищувальних та транспортуючих робочих органів дозволяє ефективніше очищувати ворох коренеплодів від грунтових і рослинних домішок, проте значно ускладнює конструкцію машини і збільшує габарит по довжині.

Метою дослідження $є$ підвищення якості очищення коренеплодів під час їх викопування шляхом моделювання робочої поверхні очисника викопувального робочого органа. 


\section{Матеріали та методи}

Теоретико-експериментальні дослідження проводилися 3 використанням методів прикладної геометрії, землеробської механіки, дисперсійного аналізу та програмного додатку MS Excel. Проби вороху коренеплодів відбиралися відповідно до методичних розробок Інституту біоенергетичних культур і цукрових буряків.

\section{Результати досліджень та обговорення}

Поміж сучасних самохідних бурякозбиральних комбайнів i причіпних коренезбиральних машин найпоширенішими $\epsilon$ ті, що оснащені дисковими викопувальними робочими органами різних конструкцій: РКМ-6-01 «Днепромаш-Инвест»; КС-6 та іï модифікації «Тернопільський комбайновий завод»; Holmer, Vervaet, Parma, Grimme (Німеччина); Alloway, Amity (США) та інші. Перевагами копачів дискового типу $\epsilon$ їх здатність добре кришити грунт при малій кількості його забору, надійність роботи на важких грунтах і забур'янених полях, висока продуктивність, підйом коренеплодів на значну висоту (Volokha et al., 2016). Експлуатація таких копачів можлива на вищих швидкостях у порівнянні 3 кулачковими, лемешковими чи вильчастими 3 одночасним забезпеченням кращих показників технологічної надійності виконання процесу і якості первинного очищення викопаних коренеплодів від залишків грунту, гички та кореневищ бур'янів (Volokha et al., 2016).

У верхній задній частині дискового викопувального робочого органа розташовується бітер чи гвинтовий шнек, до яких подаються коренеплоди у купі із залишками підрізаної дисками скиби грунту, гички і бур'янів. Відомо, що очищувальна здатність бітерного пристрою, який виключно за рахунок удару перекидає ворох коренеплодів, є низькою, а при роботі шнека з гвинтовою навивкою, коренеплоди разом 3 рослинними та грунтовими рештками скупчуються у задній зоні шнека, особливо на забу'рянених, твердих чи перезволожених грунтах, що також призводить до зниження продуктивності виконання технологічного процесу викопування та погіршення очищення коренеплодів (Volokha et al., 2016).

Розроблені копачі включають удосконалений транспортуючий шнек-очисник 3 робочою поверхнею у формі гелікоїда прямого (Patent No. 59726, 2006) та похилого (Patent No. 78042, 2013), особливістю конструкції яких є зменшення кроку навивки Р в напрямку від центра дисків до їх периферії.

При обертанні шнека будь-яка уявна точка А його гвинтової поверхні, перемістившись із одного положення в інше у перпендикулярній до осі шнека площині опише деяку дугу повного оберту $A_{1} \wedge A_{1}^{\prime}$, а у площині рисунка переміститься вздовж цієї ж осі на відстань (долю кроку $P$ ) $A_{2} A_{2}^{\prime}$, що можна подати у вигляді формули:

$$
A_{1} \wedge A_{1}^{\prime} / 360^{\circ}=A_{2} A_{2}^{\prime} / P
$$

звідки:

$$
A_{1} \wedge A_{1}^{\prime}=A_{2} A_{2}^{\prime} 360^{\circ} / P
$$

Врахувавши, що крок навивки поступово зменшується ( $\left.P_{1}>P_{2}>P_{3}\right)$ отримаємо обернену залежність: із зменшенням кроку шнека збільшується швидкість обертання його робочої поверхні в результаті чого покращується інтенсивність очищення коренеплодів.

Поверхня шнека копача (Patent No. 78042, $2013)$ - похилий гелікоїд, твірна якого утворює гострий кут з віссю. Така форма робочої поверхні шнека, крок гвинтової навивки якого i нахил твірної у напрямку виконання технологічного процесу плавно зменшуються, забезпечує підвищення кутової швидкості транспортування коренеплодів. Тобто при переміщенні оберемка вороху коренеплодів шнеком створюється поступове збільшення сили тертя завдяки чому зменшуються скупчення на його поверхні i покращується очищення коренеплодів.

Експериментальні дослідження на однорядній установці, навішеній на трактор ЮМЗ7071, проводились у Державному підприємстві «Дослідне господарство Шевченківське» Інституту біоенергетичних культур i цукрових буряків. Копачі приводились в обертальний рух від вала відбору потужності трактора, a їх заглиблення регулювалось опорними колесами. Проби вороху коренеплодів відбирались у 4кратній повторності. Викопана проба після очисника потрапляла на поліетиленову плівку, що мимовільно розгорталася слідом за копачем, i відповідно до стандартної методики розділялася на фракції. Отримані дані оброблялися статистично (Volokha et al., 2016).

Як видно із рис. $1 a$, за твердості грунту вище 3,5 МПа забрудненість грудками землі діаметром більше 50 мм у разі використання експериментальних гелікоїдальних шнеків суттєво зменшувалась як у варіантах між собою (прямий, похилий), так і відносно контролю (12,3 \%, 16,9\% проти $19,8 \%$ за $\mathrm{HIP}_{05}=2,5 \%$ ). За твердості грунту 4,0-4,5 МПа забрудненість грудками зменшувалася майже вдвічі $(17,9 \%, 18,5 \%$ проти $35,7 \%$ ), (Volokha et al., 2016). 


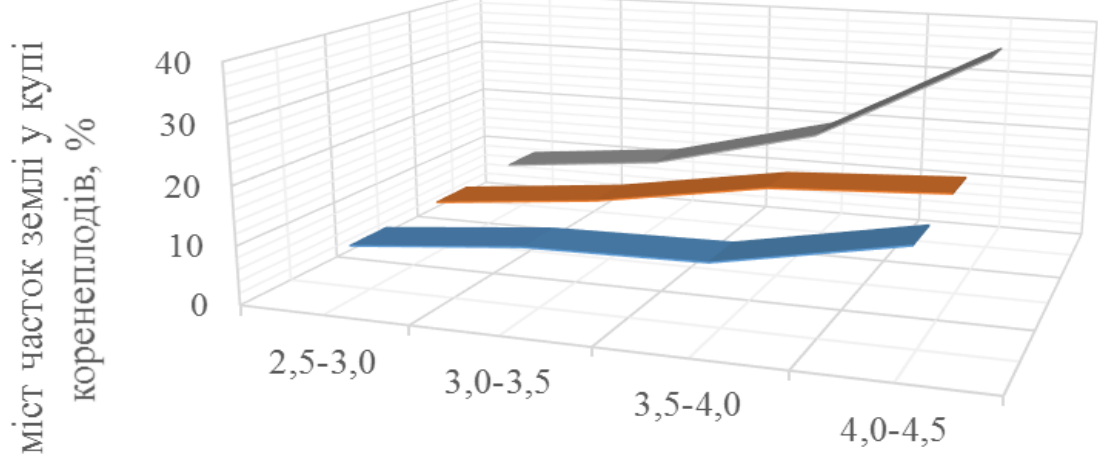

Твердість грунту, МПа

a

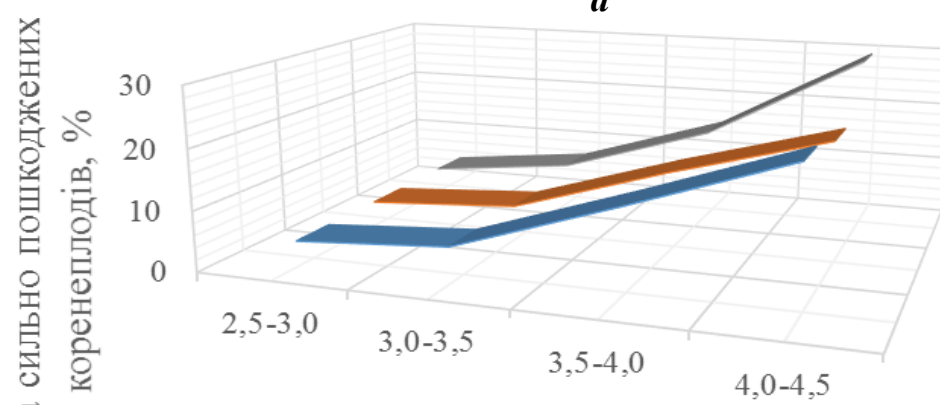

Твердість грунту, МПа

चелікоїд прямий $\square$ Гелікоїд похилий $\square$ Бітерний очисник (контроль)

б

Рuc. 1. Вплив твердості грунту і типу очисника на масу грудок землі $\varnothing>50$ мм (a) і масу пошкоджених коренеплодів (б) у купі вороху за глибини підкопування 8-10 см

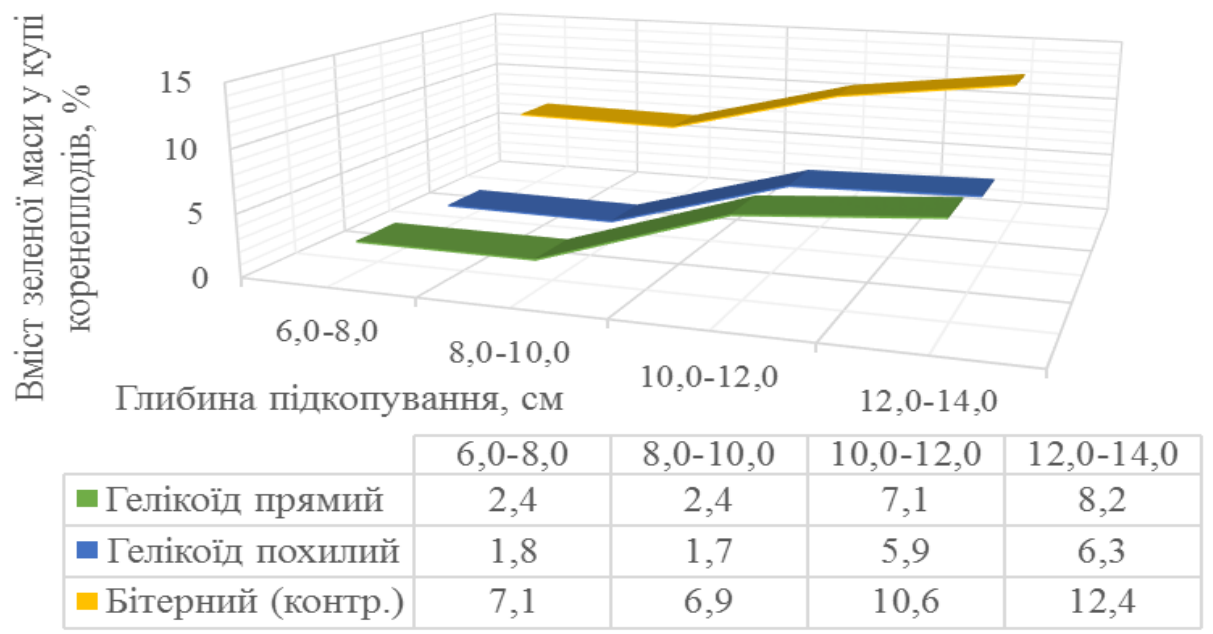

Рис. 2. Вплив глибини підкопування і типу очисника копача на кількість зеленої маси у купі коренеплодів (твердість грунту 2,5-3,0 МПа)

Вміст домішок у вигляді зеленої маси (гички i залишків бур'янів), (рис. $1 a$ ) та маса пошкоджених коренеплодів (рис. 1б) були найменшими $(1,7 \%$ та $4,3 \%$, відповідно) у разі використання похилого гелікоїдального шнека, що $\epsilon$ суттєвим зниженням проти бітерного пристрою за показником зеленої маси $(6,9 \%$, $\left.\mathrm{HIP}_{05}=3,4 \%\right) \quad$ і несуттєвим $(0,2 \%) \quad-$ за показником пошкоджень коренеплодів. Однак при роботі копачів на грунтах підвищеної твердості (понад 3,5 МПа) кількість дуже пошкоджених коренеплодів різко збільшується, 
хоча гелікоїдальні очисники отримують суттєву перевагу перед бітерними. Так, зокрема, за твердості 4,0-4,5 МПа маса пошкоджених коренеплодів похилим гелікоїдальним шнеком досягла $21,1 \%$, прямим - 23,6\%, бітерним очисником - 29,6 \% за $\mathrm{HIP}_{05}=2,7 \%$.

Отже, шнеки дискових копачів, виконані у формі гелікоїдів зі змінним кроком навивки в порівнянні 3 бітерним пристроєм покращують первинне очищення коренеплодів від грудок землі і рослинних залишків, особливо при роботі на грунтах підвищеної твердості, коли також суттєво зменшується маса пошкоджених коренеплодів.

\section{Висновки}

Існуючий в Україні потенціал біомаси енергетичних культур, серед яких i буряки цукрові, використовується біоенергетикою для переробки на паливо приблизно на $10 \%$. Поряд 3 проблемою підвищення врожайності буряків цукрових, особливо на тлі теперішнього значного скорочення посівних площ, актуальним $€$ завдання покращення якості очищення викопуваних коренеплодів. Дослідженням розроблених шнеків-транспортерів дискового копача встановлено, що при роботі очисних поверхонь 3 навивкою у формі прямого і похилого гелікоїдів змінного кроку за підвищеної твердості грунту кількість грудок діаметром більше 50 мм істотно зменшується як у варіантах між собою (прямий, похилий), так і відносно контролю. Показники вмісту домішок у вигляді зеленої маси та кількості пошкоджених коренеплодів за середньої твердості грунту $\epsilon$ найнижчі у разі використання похилого гелікоїдального шнека. Похилий гелікоїдальний шнек на грунтах підвищеної твердості забезпечив також зниження маси пошкоджених коренеплодів у порівнянні 3 серійним бітерним очисником.

\section{References}

Balan, V. M., Silakov, M. I., Sadovy, I. P. \& Bevz, M. M. (2000). Pamiatka buriakovoda [Monument to the beet grower]. Pohrebyshche: Asotsiatsiia «Vinnytsia tsukor» [in Ukrainian].

Chernyavskaya, L. I., Kukhar, V. N. \& Chernyavskiy A. P. (2013). Obespecheniye zavoda vysokokachestvennym syryem [Providing the plant with high-quality raw materials]. Sakhar, 9, 29-34 [in Russian].

Doroshenko, Y. O., Volokha, M. P. \& Boldyreva, L. V. (2013). Patent Ukrainy 78042. Kyiv: Ukrainskyi instytut intelektualnoi vlasnosti [in
Ukrainian].

Holovach, I. V., Prysiazhnyi, V. H. \& Wesołowski, M. (2012). Rozrobka vdoskonalenoi ochystky prychipnoi korenezbyralnoi mashyny [Development of advanced cleaning of the trailed root-harvesting machine]. Zbirnyk naukovykh prats Vinnytskoho natsionalnoho ahrarnoho universytetu. Ser. Tekhnichni nauky, 11 (1), 128-132 [in Ukrainian].

Koreneplody tsukrovoho buryaka dlya promyslovoho pereroblyannya. Tekhnichni umovy (2014) [Sugar beet roots for industrial processing. Specifications] DSTU 4327:2013. Natsionalnyy standart Ukrayiny. Kyiv: Derzhspozhyvstandart Ukrayiny [in Ukrainian].

Kuhar, V. N.,

Chernyavskaya, L. I., Chernyavskiy, A. P. \& Potelchak, V. A. (2013). Vyrashchivaniye svekly, eye uborka i khraneniye $\mathrm{v}$ fermerskikh khazyaystvakh: zarubezhnyy opyt [Growing beets, harvesting and storing them on farms: foreign experience]. Tsukor Ukrainy, 3, 40-45 [in Russian].

Logush, I. V., Kyryk, O. M. \& Shatrov, R. V. (2019). Porivnialnyi analiz vplyvu biopalyva na pokaznyky roboty dyzelia [Comparative analysis of the impact of biofuels on diesel performance]. Machinery \& Energetics. Journal of Rural Production Research, 10 (3), 133-138. doi: 10.31548/machenergy.2019.03.133-138 [in Ukrainian].

Polishchuk, V. M., Golopura, S. M., Biletskii, V. R. \& Styrankevych, G. R. (2018). National-economy application of diesel biofuels. Naukovyi visnyk Natsionalnoho universytetu bioresursiv $i$ pryrodokorystuvannia Ukrainy. Ser. Tekhnika ta enerhetyka APK, 297, 123-127. doi: 10.31548/machenergy.2018.03.123-127.

Volokha, M. \& Boldyreva, L. (2016). Primary cleaning of sugar beet roots from lumps of earth - a reserve for the preservation of fertile soils. Ecological security of the state: abstracts of reports of the X AllUkrainian scientific-practical conference of young scientists and students (pp. 139-140). Kyiv: NAU.

Yurchuk, V. P., Volokha, M. P., Bashta, O. T. \& Boldyreva, L. V. (2006). Patent Ukrainy 59726. Kyiv: Ukrainskyi instytut intelektualnoi vlasnosti [in Ukrainian].

Zheliezna, T. A., Drahniev, S. V., Bashtovyi, A. I. \& Rohovskyi, I. L. (2018). Perspektyvy vyrobnytstva i spozhyvannia biopalyv druhoho pokolinnia v Ukraini [Prospects for the production and consumption of second-generation biofuels in Ukraine]. Naukovyi visnyk Natsionalnoho universytetu bioresursiv $i$ pryrodokorystuvannia Ukrainy. Ser. Tekhnika ta enerhetyka APK, 296, 61-66. doi: 10.31548 / machenergy.2018.02.061-066 [in Ukrainian]. 